\title{
Pt-Ce-soot generated from fuel-borne catalysts: soot oxidation mechanism
}

\author{
K. Krishna and M. Makkee* \\ Reactor and Catalysis Engineering, DelftChemTech, Delft University of Technology, Julianalaan 136, 2628 BL Delft, The Netherlands
}

\begin{abstract}
Soot containing Ce-, Pt-, Pt-Ce-, Fe-, and Cu-fuel-borne catalysts is generated in a diesel engine, is characterised by XRD, and studied in oxidation with $\mathrm{O}_{2}$ and $\mathrm{NO}+\mathrm{O}_{2}$ under various reaction conditions. Fe-, Pt-Ce- and Ce-soot are oxidised at lower temperature with $\mathrm{O}_{2}$, compared with Pt-soot, and the opposite trend is observed with $\mathrm{NO}+\mathrm{O}_{2}$. NO is oxidised to $\mathrm{NO}_{2}$ more efficiently over Pt-soot and decreased the soot oxidation temperature by about $150{ }^{\circ} \mathrm{C}$, compared with Ce-, $\mathrm{Fe}$ - or Pt-Ce-soot. On the other hand, $\mathrm{NO}_{2}$ is most efficiently utilised over the $\mathrm{Pt}-\mathrm{Ce}$ - and Ce-soot. The soot oxidation under the different feed gas conditions demonstrates that nitrate species are involved in the oxidation of $\mathrm{Ce}$ - and $\mathrm{Pt}-\mathrm{Ce}$-soot. The oxidation species with the decreasing order of activity are: (1) nitrates, (2) $\mathrm{NO}_{2}$, (3) lattice oxygen, and (4) gas-phase oxygen. All the above species are involved in the oxidation of $\mathrm{Pt}-\mathrm{Ce}$-soot.
\end{abstract}

KEY WORDS: diesel soot; fuel-borne catalyst; Pt; Ce; mechanism.

\section{Introduction}

Diesel engine exhaust gases contribute significantly to urban and global air pollution and despite emissions of hydrocarbon (HC) and $\mathrm{CO}$ from diesel exhaust gases are low and those can be easily converted by using a diesel oxidation catalyst (DOC) [1]. Though the improvements in the modern diesel engine design and combustion process will lead to decreased emissions of both $\mathrm{NO}_{x}$ $\left(\mathrm{NO}+\mathrm{NO}_{2}\right.$, mainly present as $\left.\mathrm{NO}\right)$ and particulates (soot or carbon particulates), these are not enough to meet the future legislations. During most of the diesel engine operation period the exhaust gas temperatures are around $300{ }^{\circ} \mathrm{C}$ and that temperature is too low for initiating continuous un-catalysed soot oxidation with $\mathrm{O}_{2}$ or $\mathrm{NO}_{2}$ [2]. Therefore, the heat necessary for soot burning is generated by diesel fuel oxidation (active regeneration), which is an inefficient process. From energy considerations and system design, an ideal particulate removal unit would minimise the temperature for continuous or induced regeneration of the soot filter. The two most popular technologies to decrease the soot oxidation temperature and, thereby, the energy requirement are: (i) catalysed soot filter that converts $\mathrm{NO}$ to $\mathrm{NO}_{2}$ which in turn oxidises soot [3], and (ii) fuelborne catalyst (FBC), that oxidises the soot mainly with $\mathrm{O}_{2}$ as well as to some extent with NO [4]. The soot oxidation with oxygen is insignificant in a catalysed soot filter; this mainly arises due to from the poor contact between the catalyst and the soot [5].

The most widely implemented diesel particulate filters (DPF) for the passenger cars are developed by PSA, which meet the Euro IV particulate matter PM emission

\footnotetext{
* To whom correspondence should be addressed.

E-mail: m.makkee@tudelft.nl
}

standards [4]. This DPF system uses ceria or ceria-iron based fuel-borne catalysts and a silicon carbide $(\mathrm{SiC})$ wall flow filter to collect and oxidise PM. Either injecting the fuel to increase the temperature of the filter can regenerate the filter or under certain driving conditions the $\mathrm{FBC}$ alone is able to perform filter regeneration. Using a fuel-borne catalyst the major problem of contact between catalyst and soot is overcome and un-catalysed soot filters can be used to capture and oxidise the soot. Depending on the type of fuel-borne catalysts used, the soot can be oxidised with $\mathrm{O}_{2}$ or with $\mathrm{O}_{2}+\mathrm{NO}_{2}[4,6,7]$. The significant advantage of fuelborne catalysts is further realised in the presence of $\mathrm{SO}_{2}$, which does hardly influence the soot oxidation behaviour. The FBC-DPF system is economic and reliable compared with catalysed soot filters. A variety of fuelborne catalysts are proposed, the examples of fuel-borne catalysts studied are $\mathrm{Ce}, \mathrm{Fe}, \mathrm{Ce}-\mathrm{Fe}, \mathrm{Pt}, \mathrm{Pt}-\mathrm{Ce}, \mathrm{Mn}$, and $\mathrm{Cu}[4,6,7]$. By utilising a combination of fuel-borne catalysts, the regeneration can be faster, ash built up can be small and also the balance-point temperature can be reduced. A balance-point temperature is the lowest temperature in a filter at which the amount of soot captured from the exhaust stream on the filter is in equilibrium with the amount of soot oxidised in the same time frame.

Though enough NO is present in the feed gas, the rate of $\mathrm{NO}$ oxidation to $\mathrm{NO}_{2}$ over $\mathrm{Ce}$ or $\mathrm{Ce}-\mathrm{Fe}$ fuel-borne catalysts is not efficient and, therefore, the more powerful oxidant $\left(\mathrm{NO}_{2}\right)$ cannot be extensively generated. Bimetallic fuel-borne catalysts containing ultra low concentrations of $\mathrm{Pt}-\mathrm{Ce}$ has shown to decrease the balance point temperature to around $275-300{ }^{\circ} \mathrm{C}[6,7]$. This is the lowest balance point achieved among the many combinations of fuel additives and catalysed soot 
filters studied so far. The additional benefit by using a $\mathrm{Pt}-\mathrm{Ce}$ fuel-borne catalyst is that it forms a Pt catalyst coating on the exhaust gas system and on the filter. This deposited $\mathrm{Pt}$ is able to significantly oxidise $\mathrm{NO}$ to $\mathrm{NO}_{2}$ and, therefore, additionally decrease in the balancepoint temperature is observed. Further advantages of using the $\mathrm{Pt}-\mathrm{Ce}$ fuel-borne catalysts include the resistance to sulphur poisoning. Using the ultra low dosage of $\mathrm{Pt}-\mathrm{Ce}(<8 \mathrm{ppm})$ fuel-borne catalyst the frequency of a filter cleaning could be reduced significantly due to less ash accumulation. This will have significant advantage over a catalysed soot filter.

\section{Experimental}

\subsection{Materials and characterisation}

Ce (50 ppm), Pt (50 ppm), Pt-Ce-soot (2 ppm Pt and $30 \mathrm{ppm} \mathrm{Ce})$, Cu-soot (100 ppm), and $\mathrm{Fe}(44 \mathrm{ppm})$ containing soot are generated from the respective fuelborne catalyst additives (concentration given in parenthesis is the amount added to the fuel) in a real diesel engine $[6,7]$. The diesel engine used for the soot collection (at $75 \%$ load) and the filter evaluation was a two cylinder LPW2, produced by Lister-Petter, UK, and did not fulfil the Euro emission standards. The diesel fuels that were used during the programme were standard EN590 fuels ( $\sim 500$ ppm sulphur), summer specification, and Shell V-Power Diesel $(<10 \mathrm{ppm}$ sulphur). The metal fuel additives used in the project are listed in Table 1. Soot samples are collected by maintaining the back pressure of the exhaust system at 0.5 bar using a slipstream valve. The collected soot was scraped of the filter and sieved with a $250 \mu \mathrm{m}$ sieve.

Printex-U from Degussa S.A. is used as a model soot for the comparison of the oxidation rates. About $2.5 \mathrm{wt} \% \mathrm{Pt} / \mathrm{Al}_{2} \mathrm{O}_{3}\left(\mathrm{Pt} / \mathrm{Al}_{2} \mathrm{O}_{3}\right)$ catalyst is obtained from Engelhard Corporation, USA. $\mathrm{Ce}\left(\mathrm{NO}_{3}\right)_{3} \cdot 6 \mathrm{H}_{2} \mathrm{O}$ is used as a catalyst to study soot oxidation in a tight contact with the catalyst (prepared by mixing the cerium nitrate and soot in a mortar) in DRIFT cell connected to mass spectrometer MS. Selected soot samples are characterised by XRD analysis.

\subsection{Soot oxidation}

Soot oxidation in $100 \mathrm{ml} / \mathrm{min}$ air is studied in a thermo-gravimetric analyser (TGA/SDTA851 $1^{\mathrm{e}}$, Mettler Toledo), from room temperature RT up to $800{ }^{\circ} \mathrm{C}$ with

Table 1

Fuel-borne catalysts and its source

\begin{tabular}{ll}
\hline Metal & \multicolumn{1}{c}{ Additive } \\
\hline $\mathrm{Pt}$ & Platinum Platinum Plus 3100 \\
$\mathrm{Ce}$ & Cerium Rhône-Poulenc DPX9 \\
$\mathrm{Cu}$ & Copper Lubrizol OS-96401 \\
$\mathrm{Fe}$ & Iron Aldrich Ferrocene \\
\hline
\end{tabular}

a $10{ }^{\circ} \mathrm{C} / \mathrm{min}$ heating rate. The soot sample was diluted with excess of silicon carbide in order to minimise the influences of heat and oxygen mass transfer phenomena on the soot oxidation rates.

A loose contact mixture of $80 \mathrm{mg}$ of $\mathrm{Pt} / \mathrm{Al}_{2} \mathrm{O}_{3}$ (when used) and $20 \mathrm{mg}$ of soot (with and with out fuel-borne catalyst), mixed with a spatula and diluted with $400 \mathrm{mg}$ of $\mathrm{SiC}$ is packed between two quartz wool plugs in a tubular quartz reactor. Soot oxidation is studied with $200 \mathrm{ml} / \mathrm{min}$ of $10 \mathrm{vol} \% \mathrm{O}_{2}$ or $\mathrm{NO}_{x}+10 \mathrm{vol} \% \mathrm{O}_{2}$ in Ar. A (non-dispersed infra-red) NDIR analyser is used to monitor the reactant and product gases $\mathrm{CO}_{2}, \mathrm{CO}$, and NO. $\mathrm{NO}_{2}$ is calculated from the difference of $\mathrm{NO}$ inlet and outlet concentrations.

\section{Results}

The X-ray diffractograms of the catalyst-soot samples as shown in figure 1a indicate that diffraction peaks correspond to the fuel-borne catalyst in addition to the diffraction bands of graphite sheets. The Pt-soot, generated from $50 \mathrm{ppm} \mathrm{Pt}$ additive, shows sharp diffraction peaks corresponding to $\mathrm{Pt}^{\circ}$. This indicates that there are large Pt particles present in the range off over $10 \mathrm{~nm}$. In the $\mathrm{Pt}-\mathrm{Ce}$-soot, generated from $2 \mathrm{ppm} \mathrm{Pt}$ to $30 \mathrm{ppm} \mathrm{Ce}$ additive in from a fuel containing $500 \mathrm{ppm}$ sulphur, prominent diffraction peaks, corresponding to $\mathrm{Ce}_{2}\left(\mathrm{SO}_{4}\right)_{3}$ and weak peaks corresponding to $\mathrm{CeO}_{2}$, are evident. The diffractions, corresponding to $\mathrm{Pt}$, are not observed in the Pt-Ce-soot. The Pt-Ce-soot is oxidised in $5000 \mathrm{ppm} \mathrm{NO}+10 \mathrm{vol} \% \mathrm{O}_{2}$ in $\mathrm{Ar}$ at $350{ }^{\circ} \mathrm{C}$ in order to see the changes that occur in the soot and the fuel-borne catalyst structure due to the progressive soot burning (figure 1b). Essentially all diffraction peaks, that are observed in the original $\mathrm{Pt}-\mathrm{Ce}$-soot, are present in the $70 \%$ oxidised Pt-Ce-soot with an increased intensity. The important observation is that even in $70 \%$ oxidised soot significant diffractions due to graphitic sheets are present.

All fuel-borne catalysts have shown a significant increase in the soot oxidation activity compared to an un-catalysed printex-U soot oxidation (figure 2). Generally, the Pt containing catalysts do not show an improved oxidation. In the present study Pt, however, is present as large crystallites in the over $10 \mathrm{~nm}$ range and such a large Pt crystallite is able to oxidise the soot. A relatively larger improvement in soot oxidation rates can be observed over the $\mathrm{Fe}$-soot and $\mathrm{Pt}-\mathrm{Ce}$-soot compared to the Pt-soot and printex-U soot. Retailleau et al. [8] have shown that around $50 \%$ of the fuel-borne catalyst ends up as sulphate, which on heating decomposes to $\mathrm{Ce}_{2} \mathrm{O}_{2} \mathrm{~S}$ like phase that is capable for the soot oxidation. However, from XRD no such transformation was evident in the present study and the majority of fuel-borne catalyst ended up as cerium sulphate, even after $70 \%$ soot conversion in the presence of $\mathrm{NO}_{2}$. Though the 


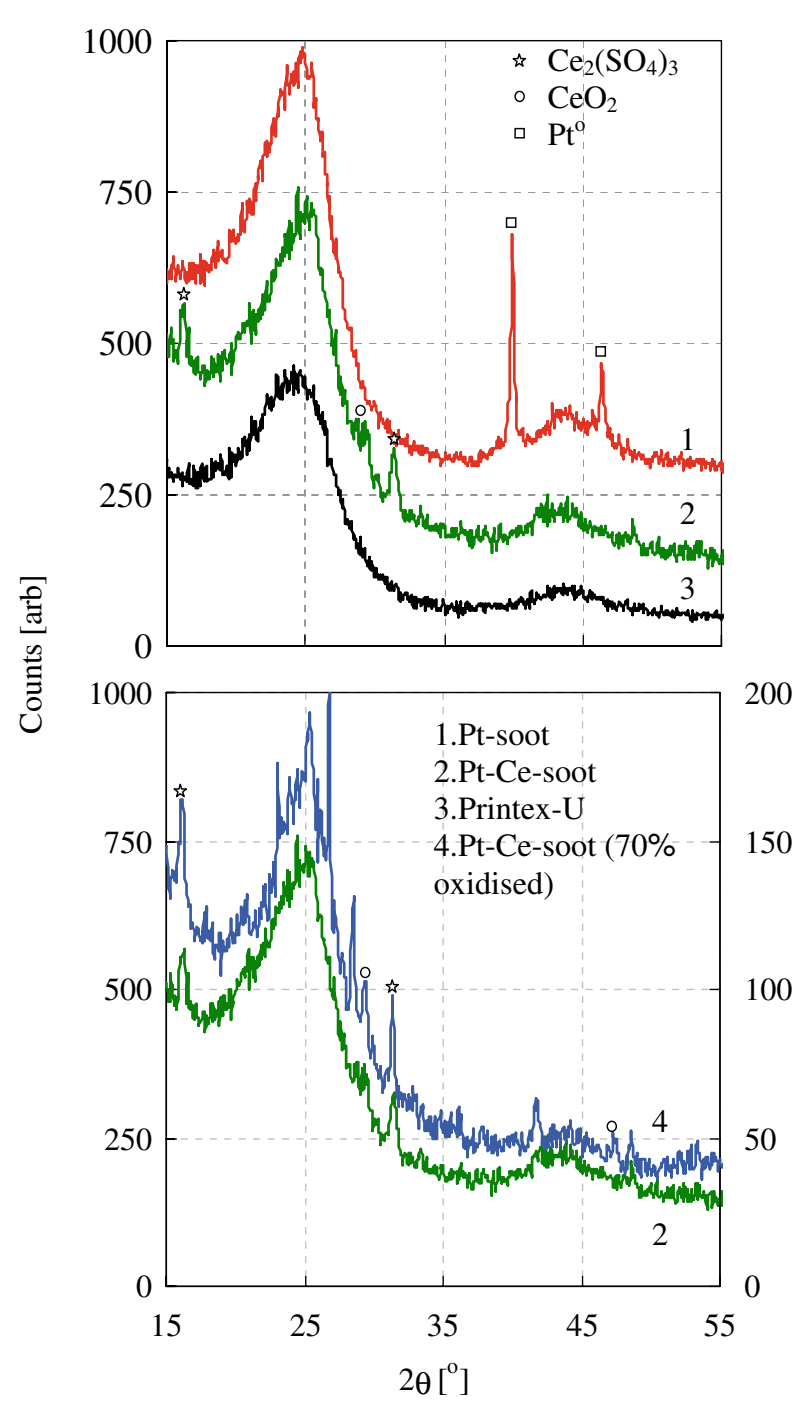

Figure 1. (a) XRD spectra of fresh soot samples as indicated; and (b) comparison of fresh $\mathrm{Pt}-\mathrm{Ce}$-soot and $70 \%$ oxidised $\mathrm{Pt}-\mathrm{Ce}$-soot. About $70 \%$ oxidised $\mathrm{Pt}-\mathrm{Ce}$-soot XRD spectra are collected under different instrument settings.

Fe-soot was not characterised by XRD, considering $500 \mathrm{ppm}$ sulphur present in the fuel used for generating $\mathrm{Fe}$-soot it can be expected that the $\mathrm{Fe}$ to some extent also forms sulphate. Furthermore, since Fe being a low atomic weight element, $44 \mathrm{ppm}$ fuel additive will lead to significantly higher iron to carbon ratio in the final $\mathrm{Fe}$-soot and part of the superior activity of the Fe-soot can be attributed to this higher molecular ratio. Compared to the Ce-soot alone, the presence of the $\mathrm{Pt}-\mathrm{Ce}-$ soot improved the oxidation activity. The soot oxidation followed the trend in decreasing activity: $\mathrm{Fe}$-soot $>\mathrm{Pt}-$ Ce-soot $>\mathrm{Pt}$-soot $\geq \mathrm{Ce}$-soot $>$ printex- $\mathrm{U}$ in the absence of $\mathrm{NO}_{x}$ in the gas phase.

Figure 3 shows fuel-borne catalyst-soot oxidation during the temperature ramping in the presence of $600 \mathrm{ppm} \mathrm{NO}+10 \mathrm{vol} \% \mathrm{O}_{2}$ in Ar. Among the fuelborne catalysts, the oxidation activity decreased in the order of Pt-soot $>\mathrm{Pt}-\mathrm{Ce}$-soot $>$ Ce-soot $>$ un-catalysed
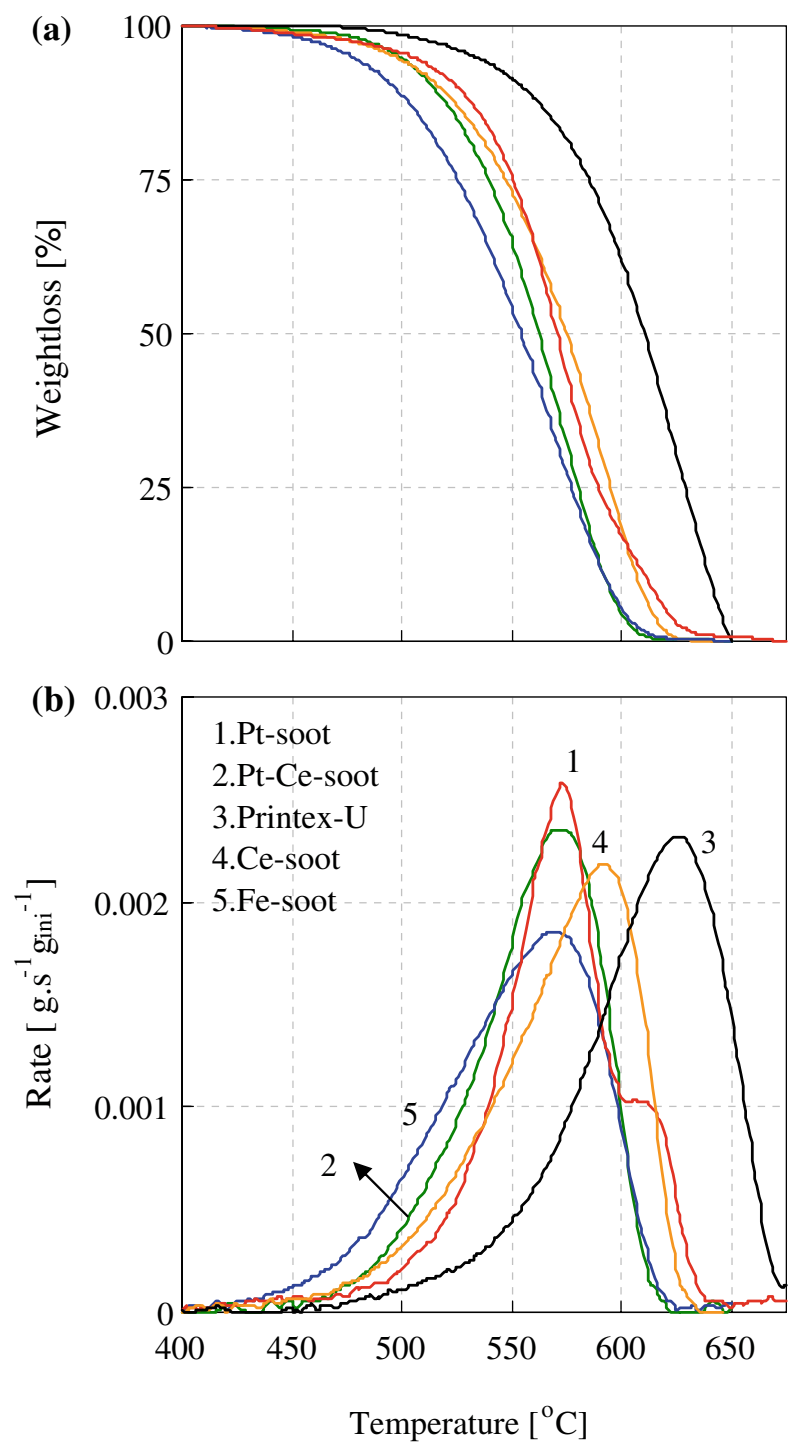

Figure 2. (a) Weight loss with temperature during soot oxidation with air; and (b) normalised soot oxidation rates. Reaction conditions: reactor-TGA, feed gas $-100 \mathrm{ml} / \mathrm{min}$ air, heating rate $-10^{\circ} \mathrm{C} / \mathrm{min}$.

soot oxidation. It is interesting to note that the Pt-soot is the least active soot in the presence of $\mathrm{O}_{2}$ alone, compared to $\mathrm{Pt}-\mathrm{Ce}$-soot, whereas it is significantly superior in the presence of NO. The main responsible oxidant for the decreasing in the soot oxidation temperature over the Pt-soot is the $\mathrm{NO}_{2}$ generated over the Pt crystallites. Figure 4a shows the $\mathrm{NO}_{2}$ slip during the soot oxidation as shown in figure 3 . The Pt-soot generated significant amounts of $\mathrm{NO}_{2}$ slip compared with the $\mathrm{Pt}-\mathrm{Ce}$-soot and $\mathrm{Ce}$-soot. It can be expected that for the $\mathrm{Pt}-\mathrm{Ce}$-soot and $\mathrm{Ce}$-soot due to the lower $\mathrm{NO}$ oxidation rates the generated $\mathrm{NO}_{2}$ is completely utilised for the soot oxidation. The trend in the $\mathrm{NO}_{2}$ slip followed the order Pt-soot $>\mathrm{Pt}-\mathrm{Ce}$ soot $>$ Ce-soot $>$ un-catalysed soot and from the $\mathrm{NO}_{2}$ slip comparison it can also be stated that the $\mathrm{Pt}-\mathrm{Ce}$-soot and Ce-soot are less active than Pt-soot in the NO oxidation to $\mathrm{NO}_{2}$, but the generated $\mathrm{NO}_{2}$ is more efficiently utilised in the soot oxidation over the former catalysts. 


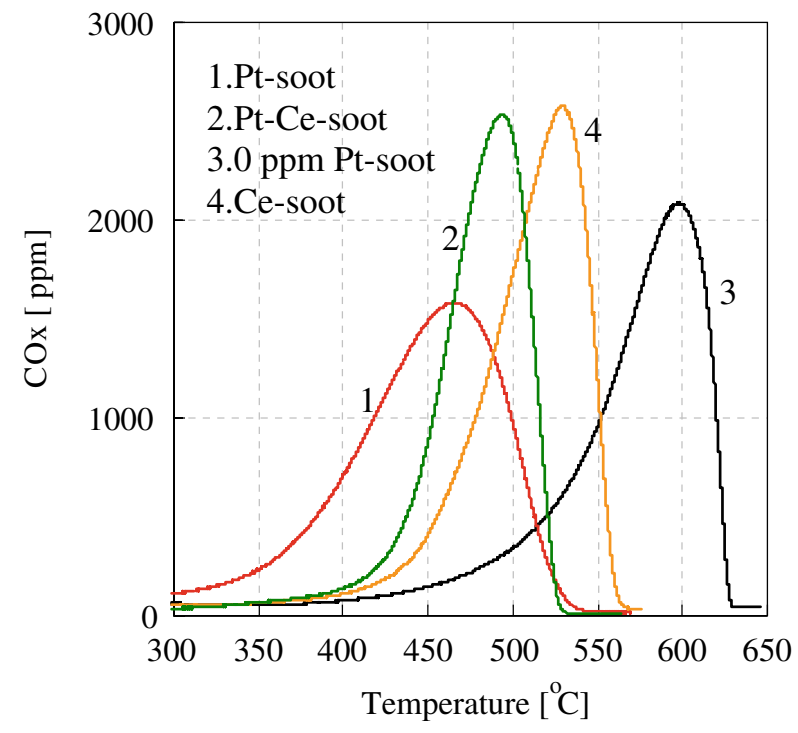

Figure 3. $\mathrm{CO}_{x}$ evolution with temperature during soot oxidation with $\mathrm{NO}+\mathrm{O}_{2}$, with increasing oxidation temperature. Reaction conditions: reactor-fixed bed, feed gas $-200 \mathrm{ml} / \mathrm{min} 600 \mathrm{ppm} \mathrm{NO}+10$ vol $\% \mathrm{O}_{2}+\mathrm{Ar}$, heating rate $-1{ }^{\circ} \mathrm{C} / \mathrm{min}$, soot $-20 \mathrm{mg}$.

Before $\mathrm{NO}$ oxidation to $\mathrm{NO}_{2}$ shown in figure $4 \mathrm{~b}$, the fuel-borne catalysts were exposed to $650{ }^{\circ} \mathrm{C}$ during soot oxidation experiment to completely removal of the soot. Based on $\mathrm{NO}_{2}$ slip (figure 4a) it was expected that $\mathrm{Pt}$ would be more active for $\mathrm{NO}$ conversion to $\mathrm{NO}_{2}$ in the absence of soot (figure $4 \mathrm{~b}$ ) compared to the presence of soot (figure 4a). It was, however, less active. On the other hand, the activity of the NO oxidation over the $\mathrm{Pt}-\mathrm{Ce}$ fuel-borne catalysts is clearly higher than that of $\mathrm{NO}_{2}$ slip and $\mathrm{Ce}$ fuel-borne catalyst did not show a significant oxidation activity. The observed NO oxidation trends over fuel-borne catalysts suggest that $\mathrm{Pt}$ alone as fuel-borne catalyst seems to sinter extensively after complete soot oxidation compared with $\mathrm{Pt}-\mathrm{Ce}$ and $\mathrm{Ce}$ alone are not very active for the NO oxidation to $\mathrm{NO}_{2}$. Based on the $\mathrm{NO}$ oxidation studies it is suggested that the main function of the $\mathrm{Ce}$ component in the $\mathrm{Pt}-\mathrm{Ce}$-soot is to stabilise Pt crystallites. These crystallites will mainly convert $\mathrm{NO}$ to $\mathrm{NO}_{2}$ resulting in an improved soot oxidation.

Figure 5 shows the oxidation of the fuel-borne catalyst-soot samples after the addition of $2.5 \mathrm{wt} \% \mathrm{Pt} / \mathrm{Al}_{2} \mathrm{O}_{3}$ in the presence of $600 \mathrm{ppm} \mathrm{NO}+10 \mathrm{vol} \% \mathrm{O}_{2}$ in Ar. Because the $\mathrm{Pt} / \mathrm{Al}_{2} \mathrm{O}_{3}$ is mixed with the fuel-borne catalyst-soot, a continuous supply of $\mathrm{NO}_{2}$ can be ensured for soot oxidation and this will eliminate $\mathrm{NO}_{2}$ dependence on fuel-borne catalyst. A completely different trend of the soot oxidation activity is observed compared to the oxidation in the presence of $\mathrm{NO}+\mathrm{O}_{2}$ or $\mathrm{O}_{2}$. Even the printex-U soot and Fe-soot are much more easily oxidised compared with the Pt-soot in the presence of $\mathrm{Pt} / \mathrm{Al}_{2} \mathrm{O}_{3}$. No significant differences are found in the $\mathrm{NO}_{2}$ slip between different combinations of fuel-borne catalyst-soot- $\mathrm{Pt} / \mathrm{Al}_{2} \mathrm{O}_{3}$ mixtures, as the $\mathrm{Pt} /$ $\mathrm{Al}_{2} \mathrm{O}_{3}$ determines most of the soot oxidation activity (figure $5 \mathrm{~b}$ ). In the presence of the $\mathrm{Pt} / \mathrm{Al}_{2} \mathrm{O}_{3}$ the soot oxidation trend is in the following order; $\mathrm{Pt}-\mathrm{Ce}$ soot $>$ printex-U soot $>$ Fe-soot $>$ Pt-soot in the presence of $\mathrm{NO}_{x}$ in the gas phase.

Figure $6 \mathrm{a}$ shows the soot oxidation activity in the presence of $5000 \mathrm{ppm} \mathrm{NO}_{2}$ at $350{ }^{\circ} \mathrm{C}$ over the $\mathrm{Pt}-\mathrm{Ce}-$ soot and printex-U soot. Both soot samples have shown a similar oxidation activity as evident from the similar $\mathrm{CO}_{x}$ concentration levels at the reactor outlet. Figure $6 \mathrm{~b}$ shows the oxygen mass balance during the reaction over the $\mathrm{Pt}-\mathrm{Ce}$-soot. The oxygen mass balance between $\mathrm{CO}_{2}+\mathrm{CO}$ at the reactor out let is similar to the NO concentration at the reactor outlet and, therefore, it can be concluded that the entire $\mathrm{CO}_{x}$ is arising from $\mathrm{NO}_{2}$. Figure 7 shows the temperature ramping experiments over the fuel-borne catalyst-soot samples with $\mathrm{NO}_{2}$, taken from the Ph.D. thesis of Jelles [9]. The Ce-soot and $\mathrm{Cu}$-soot have shown a similar activity, whereas the $\mathrm{Fe}$-soot shows a reduced activity. From the above isothermal and ramping experiments it can be argued that,

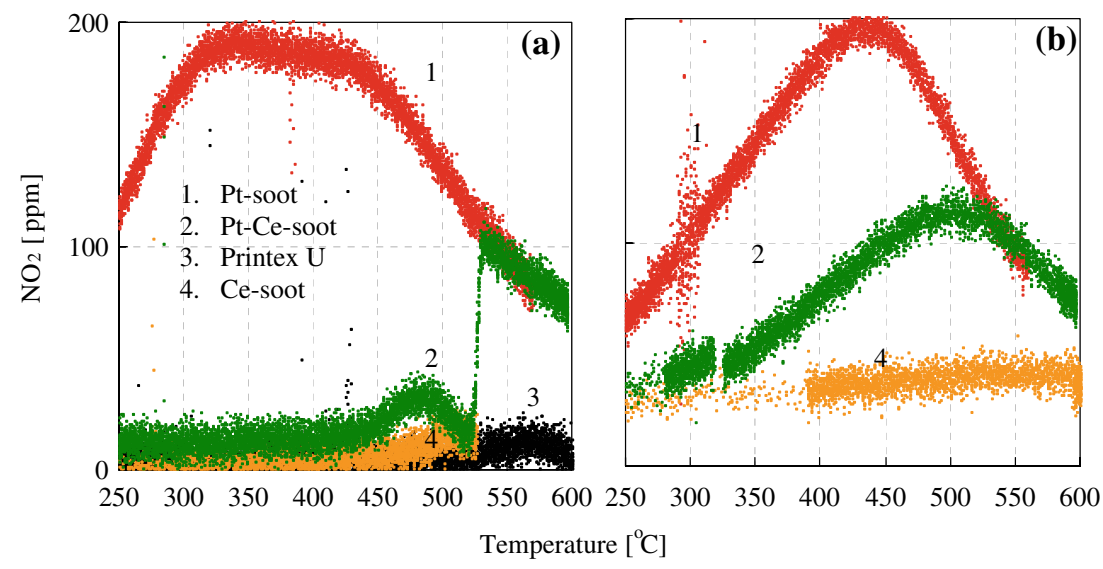

Figure 4. (a) $\mathrm{NO}_{2}$ at the reactor outlet during soot oxidation (figure 3) and (b) $\mathrm{NO}_{2}$ at the outlet after soot oxidation while cooling. Reaction conditions: reactor-fixed bed, feed gas $-200 \mathrm{ml} / \mathrm{min} 600 \mathrm{ppm} \mathrm{NO}+10 \mathrm{vol} \% \mathrm{O}_{2}+$ Ar, heating rate $-1{ }^{\circ} \mathrm{C} / \mathrm{min}$, soot $-20 \mathrm{mg}$. $\mathrm{NO}{ }_{2}=$ inlet - outlet reactor NO concentrations measured by NDIR. 

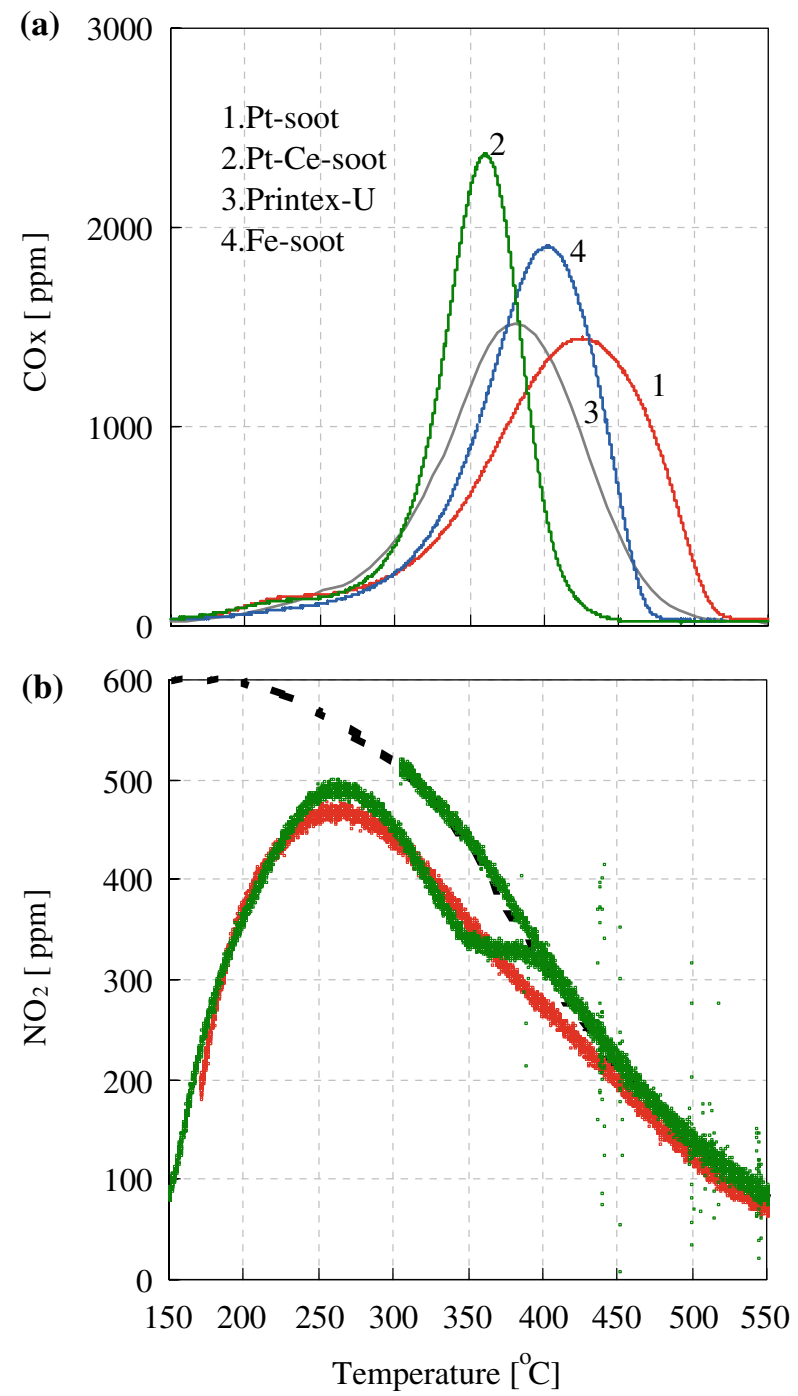

Figure 5. (a) $\mathrm{Co}_{x}$; and (b) $\mathrm{NO}_{2}$ at the reactor outlet with increasing temperature during soot oxidation with $\mathrm{NO}+\mathrm{O}_{2}+\mathrm{Pt} / \mathrm{Al}_{2} \mathrm{O}_{3}$. Reaction conditions: reactor-fixed bed, feed gas $-200 \mathrm{ml} / \mathrm{min}$ $600 \mathrm{ppm} \mathrm{NO}+10 \mathrm{vol} \% \mathrm{O}_{2}+\mathrm{Ar}$, heating rate $-1{ }^{\circ} \mathrm{C} / \mathrm{min}$. Soot $(20 \mathrm{mg})$ and $\mathrm{Pt} / \mathrm{Al}_{2} \mathrm{O}_{3}(80 \mathrm{mg})$ are mixed with a spatula + silicon carbide as a diluent.

if the $\mathrm{NO}_{2}$ is the only oxidant, fuel-borne catalysts do not play a significant role in the determination of the soot oxidation performance, in agreement with the proposal that the $\mathrm{NO}_{2}$ reaction with the soot is un-catalysed.

Figure 8 shows the soot oxidation with $5000 \mathrm{ppm}$ $\mathrm{NO}_{2}+10 \mathrm{vol} \% \mathrm{O}_{2}$ at $350{ }^{\circ} \mathrm{C}$ over the $\mathrm{Pt}-\mathrm{Ce}$-soot and printex-U soot. The $\mathrm{CO}_{x}$ concentration at the reactor outlet increased over both soot samples compared with the oxidation using $\mathrm{NO}_{2}$ alone due to the $\mathrm{Pt}-\mathrm{Ce}$ catalysed soot oxidation, to some extent using $\mathrm{O}_{2}$, as an oxidant. The extent of the increase cannot, however, be explained based on either the $\mathrm{NO}$ recycle to $\mathrm{NO}_{2}$ and the direct soot oxidation with $\mathrm{O}_{2}$, catalysed by $\mathrm{Ce}$.

Figure 9 shows the oxidation of soot mixed with $\mathrm{Pt} /$ $\mathrm{Al}_{2} \mathrm{O}_{3}$ at $350{ }^{\circ} \mathrm{C}$ in the presence of $\mathrm{NO}+\mathrm{O}_{2}$ in the feed
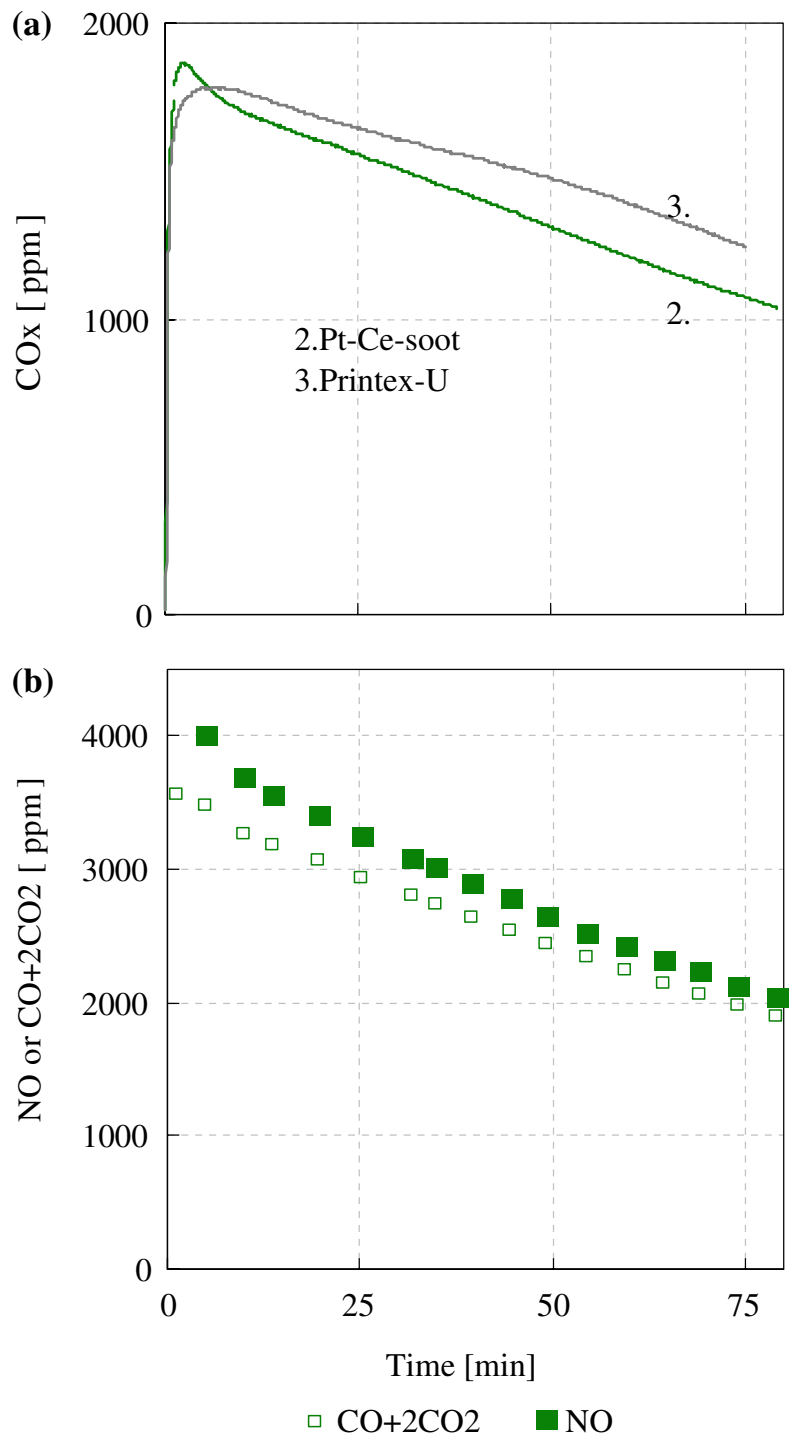

Figure 6. (a) $\mathrm{CO}_{x}$ over $\mathrm{Pt}-\mathrm{Ce}$-soot and Printex- $\mathrm{U}$ soot; and (b) oxygen mass balance ( $\mathrm{NO}$ and $2 \mathrm{CO}_{2}+\mathrm{CO}$ ) over Pt-Ce-soot during isothermal soot oxidation with $\mathrm{NO}_{2}$ at $350{ }^{\circ} \mathrm{C}$. Reaction conditions: reactorfixed bed, feed gas $-200 \mathrm{ml} / \mathrm{min} 5000 \mathrm{ppm} \mathrm{NO} \mathrm{N}_{2}+\mathrm{Ar}$, soot $-20 \mathrm{mg}$.

gas. The Pt-Ce-soot has shown a significantly higher soot oxidation activity compared with the rest of the soot samples despite of a similar or higher amount of fuel-borne catalyst present in the Pt-soot and Ce-soot samples. Various possibilities should be considered to explain the superior performance of $\mathrm{Pt}-\mathrm{Ce}$-soot and Ce-soot: (i) the main oxidant for the oxidation of the different soot samples is $\mathrm{NO}_{2}$, (ii) $\mathrm{NO}_{2}$ is mainly produced over the $\mathrm{Pt} / \mathrm{Al}_{2} \mathrm{O}_{3}$ and the fuel-borne catalyst has very small influence if any and, so (iii) the NO recycle over the $\mathrm{Pt}-\mathrm{Ce}$-soot as a reason for the improved activity can be ruled out, as all the fuel-borne catalystsoot compositions have this ability to produce $\mathrm{NO}_{2}$ from the externally added $\mathrm{Pt} / \mathrm{Al}_{2} \mathrm{O}_{3}$ catalyst. If this has to be an important step then the Pt-soot should show a significantly higher soot oxidation activity. 


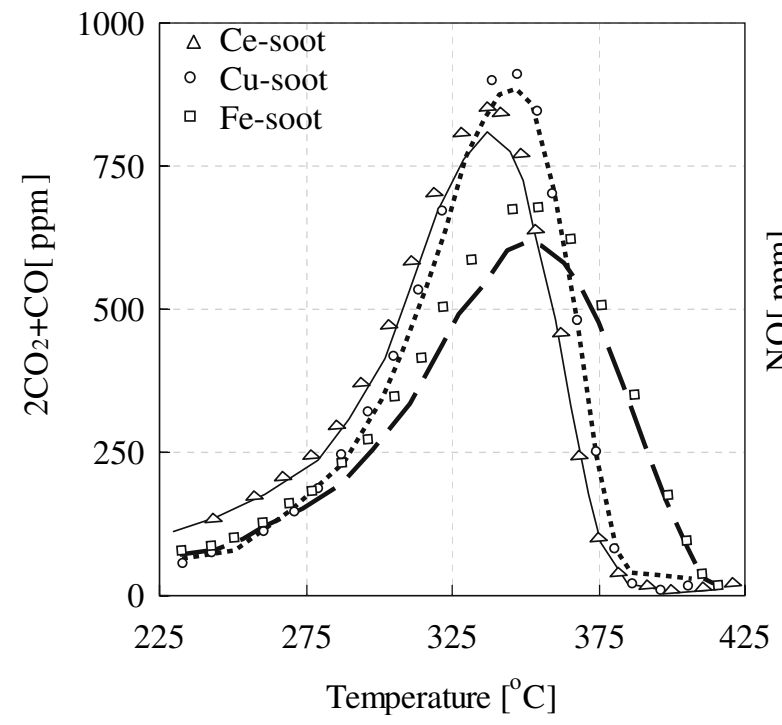

Figure 7. Catalyst-soot oxidation with $\mathrm{NO}_{2}$ with increasing temperature. Reaction conditions: reactor-fixed bed, feed gas $-200 \mathrm{ml} / \mathrm{min}$ $2500 \mathrm{ppm} \mathrm{NO} \mathrm{NO}_{2}+\mathrm{Ar}$, heating rate $-0.2{ }^{\circ} \mathrm{C} / \mathrm{min}$, soot $-20 \mathrm{mg}$.

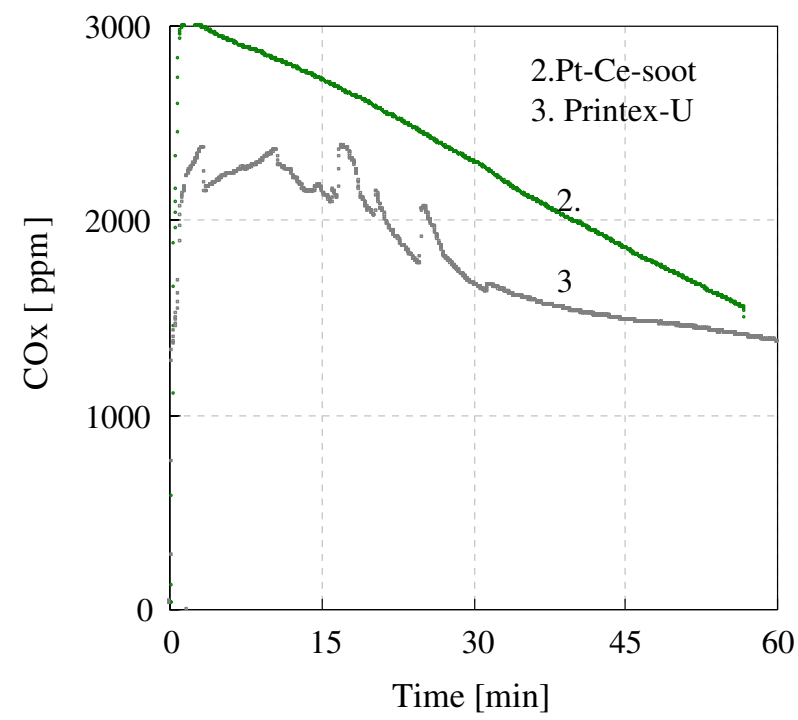

Figure 8. $\mathrm{CO}_{x}$ over Pt-Ce-soot and Printex- $\mathrm{U}$ soot during isothermal soot oxidation with $\mathrm{NO}_{2}+\mathrm{O}_{2}$ at $350{ }^{\circ} \mathrm{C}$. Reaction conditions: reactor-fixed bed, feed gas $-200 \mathrm{ml} / \mathrm{min} 5000 \mathrm{ppm} \mathrm{NO} \mathrm{NO}_{2}+10 \mathrm{vol} \%$ $\mathrm{O}_{2}+\mathrm{Ar}$, soot $-20 \mathrm{mg}$.

The superior oxidation performance of the $\mathrm{Pt}-\mathrm{Ce}-$ soot and Ce-soot is only observed in the presence of excess $\mathrm{NO}_{2}+\mathrm{O}_{2}$ or $\mathrm{NO}+\mathrm{O}_{2}+\mathrm{Pt} / \mathrm{Al}_{2} \mathrm{O}_{3}$. In order to explain such a behaviour especially in the presence of $\mathrm{Pt} / \mathrm{Al}_{2} \mathrm{O}_{3}$ catalyst Jelles et al. $[6,7,9]$ have proposed that ceria catalyses the soot oxidation by $\mathrm{NO}_{2}$ (apart from direct soot oxidation with $\mathrm{NO}_{2}$ ). The $\mathrm{NO}_{2}$ decomposes over $\mathrm{CeO}_{2}$ to $\mathrm{NO}$ and adsorbed ' $\mathrm{O}$ '' ' on $\mathrm{CeO}_{2}$ surface and the adsorbed $\mathrm{O}^{*}$ will efficiently oxidise the soot. If the above mechanism is operating, then $\mathrm{Pt}-\mathrm{Ce}$-soot could have shown a superior activity with $\mathrm{NO}_{2}$ alone as
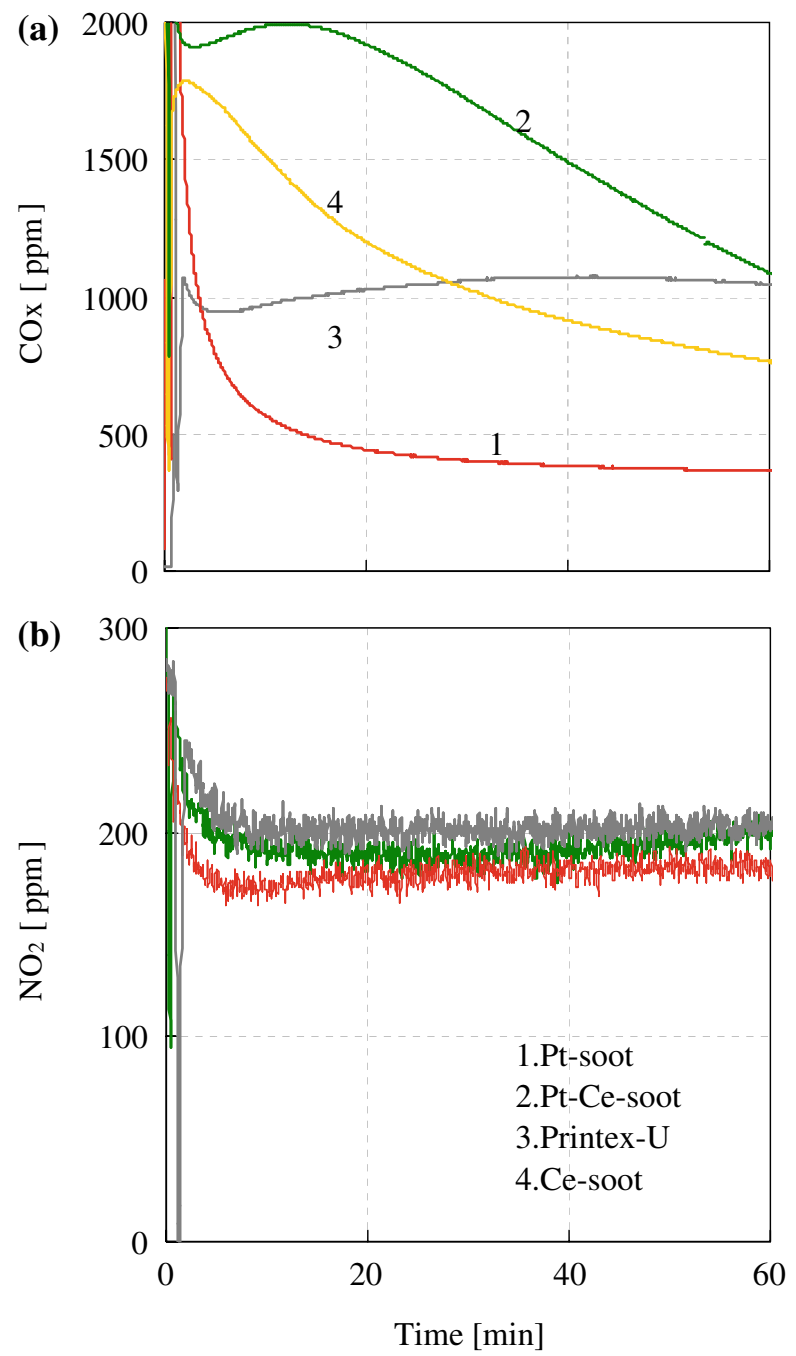

Figure 9. (a) $\mathrm{CO}_{x}$, and (b) $\mathrm{NO}$ at the reactor during Pt-Ce-soot and Printex-U soot oxidation with $300 \mathrm{ppm} \mathrm{NO}+\mathrm{O}_{2}$ at $350{ }^{\circ} \mathrm{C}$. Reaction conditions: reactor-fixed bed, feed gas - $200 \mathrm{ml} / \mathrm{min} 300 \mathrm{ppm}$ $\mathrm{NO}_{2}+10 \mathrm{vol} \% \mathrm{O}_{2}+\mathrm{Ar}$, soot $-20 \mathrm{mg}$.

an oxidant compared with the other fuel-borne catalystsoot samples. This is, however, not the case. Therefore, there should be another mechanistic routes of the soot oxidation to explain the superior performance of $\mathrm{Pt}-\mathrm{Ce}-$ soot in the presence of $\mathrm{NO}_{2}+\mathrm{O}_{2}$ or $\mathrm{NO}+\mathrm{O}_{2}+\mathrm{Pt} /$ $\mathrm{Al}_{2} \mathrm{O}_{3}$. Under these feed gas conditions one can expect apart from the known gas-phase species the formation of surface nitrates on ceria. Decomposition products of nitrates are very powerful oxidants in the soot oxidation. Because the ceria is in a tight contact with the soot the transfer of decomposed nitrates to soot surface should be efficient.

Figure 10 shows the decomposition of $\mathrm{Ce}\left(\mathrm{NO}_{3}\right)_{3}$ and $\mathrm{Ce}\left(\mathrm{NO}_{3}\right)_{3}+$ soot (4:1 tight contact mixture due the mixing in an mortar) in He in a DRIFT cell connected to mass spectrometer MS. The cerium nitrate precursor decomposition alone gives $\mathrm{NO}_{2}+\mathrm{O}_{2}$ in the gas phase $\left(2 \mathrm{Ce}\left(\mathrm{NO}_{3}\right)_{3} \rightarrow 2 \mathrm{CeO}_{2}+6 \mathrm{NO}_{2}+\mathrm{O}_{2}\right.$ ) (figure 10a). In the presence of the soot, cerium nitrate decomposed at a 


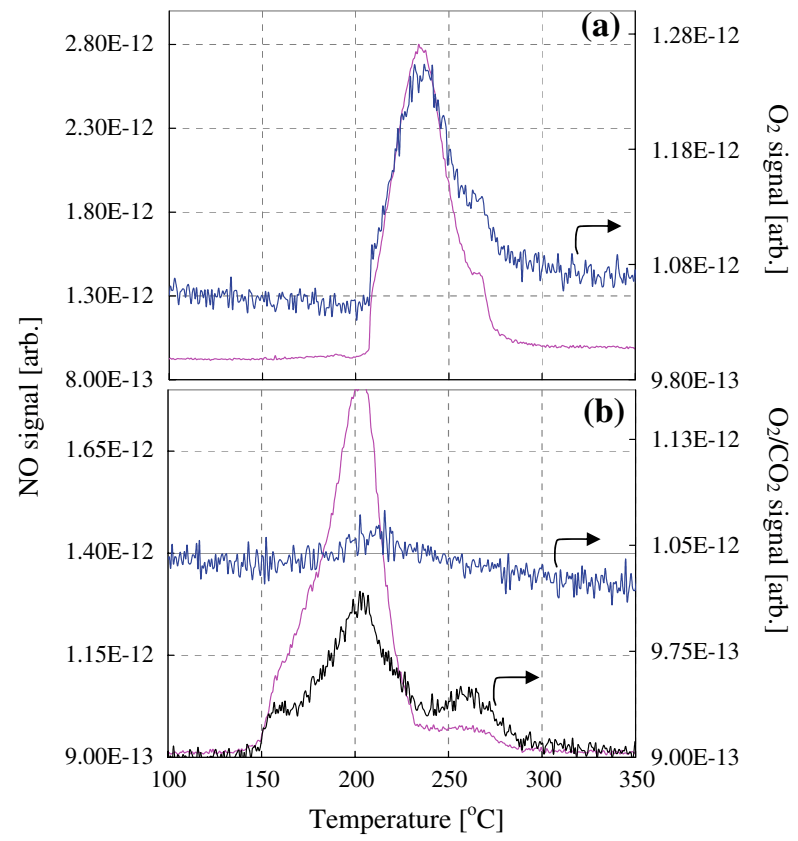

Figure 10. MS analysis of (a) $\mathrm{Ce}\left(\mathrm{NO}_{3}\right)_{3}$, and (b) $\mathrm{Ce}\left(\mathrm{NO}_{3}\right)_{3}+$ Printex$\mathrm{U}$ soot decomposition in He. Reaction conditions: reactor-DRIFT cell connected to MS, feed gas $-20 \mathrm{ml} / \mathrm{min} \mathrm{He}, \mathrm{Ce}\left(\mathrm{NO}_{3}\right)_{3}+$ soot were ground in a mortar.

lower temperature due to its reaction with the soot and no oxygen is observed (figure 10b). The absence of oxygen clearly indicates that nitrate is a primary reactant at these low temperatures around $200{ }^{\circ} \mathrm{C}$.

\section{Discussion}

The mechanistic aspects of the soot oxidation over $\mathrm{Pt} /$ support type after-treatment systems are straightforward and are extensively reported in literature. The main oxidation function arises from the Pt crystallites, on which the exhaust gas $\mathrm{NO}$ is oxidised to $\mathrm{NO}_{2}$. This formed $\mathrm{NO}_{2}$ will further react with the soot around $300{ }^{\circ} \mathrm{C}$. As the $\mathrm{NO}$ conversion to $\mathrm{NO}_{2}$ is both thermodynamically and kinetically controlled, the excess NO in the exhaust gas is necessary compared with soot $(\mathrm{NO} /$ soot $>20$ ) in order to realise a significant soot oxidation around $300{ }^{\circ} \mathrm{C}$ [2]. The main disadvantages of the catalysed soot traps arise from their durability and resistance to the $\mathrm{SO}_{3}$ poisoning, especially when used in heavy-duty applications. The fuel-borne catalysts in this respect have the advantages as the durability of the catalyst is not an issue, and $\mathrm{SO}_{2}$ is found to have a very small influence compared with catalysed soot traps [6-9]. Though the fuel-borne catalysts have been studied for the past two decades, not many mechanistic aspects on how the soot is oxidised over these catalysts are not thoroughly studied. It is assumed that the oxygen storage capacity of ceria is capable of providing locally the necessary active species for the soot oxidation. However, the reaction/characterisation studies known limited to correlate different catalyst surface properties with the soot oxidation activity, especially in the presence of $\mathrm{NO}+\mathrm{O}_{2}$. In the present study the fuel-borne catalystsoot samples (Table 1), except the Pt-soot, are generated with a fuel containing $500 \mathrm{ppm}$ of sulphur, and have been characterised. The reasons for the possible superior activity of $\mathrm{Pt}-\mathrm{Ce}$-soot compared with the other catalystsoot samples are explained by different active species in the gas phase or on the fuel-borne catalyst.

X-ray diffractograms of all soot samples essentially showed similar features (figure 1): large $\mathrm{Pt}$ crystallites are observed in the Pt-soot and $\mathrm{Ce}_{2}\left(\mathrm{SO}_{4}\right)_{3}$ and $\mathrm{CeO}_{2}$ phases are observed in the $\mathrm{Pt}-\mathrm{Ce}$-soot. No XRD observable $\mathrm{Pt}$ crystallites are detected in the $\mathrm{Pt}-\mathrm{Ce}$-soot due to the ultra low dosage of $\mathrm{Pt}$ additive (2 ppm). No major changes of the cerium sulphate phases are observed even in $70 \%$ oxidised Pt-Ce-soot. Retailleau et al. [8] have observed the decomposition of cerium sulphate as an important step, forming new phases that can activate oxygen in the soot oxidation. However, such a significant transformation of the cerium sulphate is not evident from XRD in the present study and the $\mathrm{Ce}_{2}\left(\mathrm{SO}_{4}\right)_{3}$ phases can be considered as inactive phase in the soot oxidation experiments. It is shown that the surface lattice oxygen of $\mathrm{CeO}_{2}$ is involved in the soot oxidation [10]. $\mathrm{CeO}_{2}$ supplies the lattice oxygen efficiently to soot thus creating oxygen vacancies, which are quickly filled by gas-phase oxygen and further driving the soot oxidation. It is also important to notice that, even in the $70 \%$ oxidised $\mathrm{Pt}-\mathrm{Ce}$-soot, relatively significant diffractions due to graphitic sheets are observed (figure 1b). This indicates that the soot burning is first taking place on amorphous mass in the soot particle, followed by the consumption of the graphitic sheets. This suggests that the oxidation model may not follow shrinking core formalism. This observation indicates that during soot oxidation of fuel-borne catalyst-soot, if any of the catalyst particles are buried inside the primary particle, with progressive soot oxidation these particles are exposed and could potentially increase the oxidation rate.

Since the majority of the fuel-borne catalysts are present as cerium sulphate, it can be stated that $\mathrm{Pt}$ is significantly less active compared with the ceria-soot samples with $\mathrm{O}_{2}$ (figure 2). On the other hand, in the presence of $\mathrm{NO}+\mathrm{O}_{2}$, the Pt-catalysts are significantly more active (figure 3a). The improved soot oxidation activity is obviously due to superior NO oxidation to $\mathrm{NO}_{2}$ over the Pt-soot (figure 4a), which further oxidises soot to $\mathrm{CO}_{2}$. The Ce-soot is least active and the $\mathrm{Pt}-\mathrm{Ce}-$ soot (considering low dosage of fuel-borne additive, 2 ppm Pt-30 ppm Ce) has shown moderate activity. From the higher $\mathrm{NO}$ oxidation to $\mathrm{NO}_{2}$ in the presence of soot, compared with lower $\mathrm{NO}$ oxidation activity to $\mathrm{NO}_{2}$ in the absence of soot over Pt, it can be concluded that Pt sinters in the absence of support after soot oxidation. On the other hand, the function of $\mathrm{Ce}$ in 
$\mathrm{Pt}-\mathrm{Ce}$-soot seems to stabilise $\mathrm{Pt}$ crystallites towards sintering. Pt-Ce combination will have a significantly higher impact in increasing the soot oxidation rate compared to $\mathrm{Pt}$ alone which can be expected to extensively sinter.

When fuel-borne catalyst-soot is mixed with $\mathrm{Pt} / \mathrm{Al}_{2} \mathrm{O}_{3}$ and the soot oxidation is carried out with $\mathrm{NO}+\mathrm{O}_{2}$, the $\mathrm{Pt}-\mathrm{Ce}$-soot is more reactive compared with all other soot samples (figure 5). The observed differences in the soot oxidation activity under these conditions cannot be explained based on the different extents of $\mathrm{NO}$ oxidation to $\mathrm{NO}_{2}$. If the $\mathrm{NO}$ oxidation to $\mathrm{NO}_{2}$ is the main reactant for the soot oxidation then the Pt-soot $+\mathrm{Pt} / \mathrm{Al}_{2} \mathrm{O}_{3}$ is expected to show a higher soot oxidation activity. The enhanced soot oxidation over Pt-Ce-soot should, therefore, be either due to the different nature of the soot or due to the fuel-borne $\mathrm{Pt}-\mathrm{Ce}$ catalyst. It was suggested that the $\mathrm{NO}_{2}$ formed on the supported platinum catalyst will decompose to give $\mathrm{NO}$ and adsorbed ' $\mathrm{O}$ ' on the $\mathrm{Pt}-\mathrm{Ce}$ catalyst, and such an oxygen is responsible for the high soot oxidation activity [6]. However, all the soot samples have shown a similar activity in the presence of $\mathrm{NO}_{2}$ alone (figures 6 and 7). If $\mathrm{Pt}-\mathrm{Ce}$ is catalysing the soot oxidation with $\mathrm{NO}_{2}$, then the $\mathrm{Pt}-\mathrm{Ce}$-soot is expected to show a significantly higher soot oxidation activity with $\mathrm{NO}_{2}$. The significant superior activity over $\mathrm{Pt}-\mathrm{Ce}$-soot is only observed with $\mathrm{NO}_{2}$ in the presence of $\mathrm{O}_{2}$ (figure 8) or $\mathrm{NO}+\mathrm{O}_{2}+\mathrm{Pt} /$ $\mathrm{Al}_{2} \mathrm{O}_{3}$ (figure 9). Even the Ce-soot is more reactive compared with the Pt-soot in the presence of $\mathrm{NO}+\mathrm{O}_{2}+\mathrm{Pt} / \mathrm{Al}_{2} \mathrm{O}_{3}$ (figure 9). This high activity can be hypothesised that the main reaction, that takes place under these reaction conditions, is the formation of the surface nitrates over the ceria. These nitrates are found to oxidise the soot at very low temperatures (around $200{ }^{\circ} \mathrm{C}$ ) in comparison with the gas-phase $\mathrm{NO}_{2}$ at around $300{ }^{\circ} \mathrm{C}$ (figure 10). Though $\mathrm{CeO}_{2}$ alone is capable of forming the surface nitrates, the combination of $\mathrm{Pt}$ and $\mathrm{Ce}$ shows a synergetic effect and seems to improve the rate of such nitrate formation. On the other hand, the $\mathrm{Fe}-, \mathrm{Cu}$-, and Pt-fuel-borne catalysts do not form extensively these surface nitrates and the main reactions over these catalysts are the direct soot oxidation with $\mathrm{NO}_{2}$ and $\mathrm{O}_{2}$.

Based on the experimental results, the different reactions that are important for the soot oxidation are summarised in Scheme 1. It can be concluded that the oxidation activity of the species with the decreasing order is: (1) nitrates, $\mathrm{NO}_{3}^{-}$, (2) $\mathrm{NO}_{2}$, (3) lattice oxygen, and (4) gas-phase oxygen. From the present study and that of Jelles et al. $[6,7,9]$ the hypothesis is formulated that all possible oxidation species present in the exhaust gas and on the catalyst surface (Scheme 1) can be effectively utilised in $\mathrm{Pt}-\mathrm{Ce}$-soot oxidation in comparison with any of the known catalytic systems. Furthermore, the $\mathrm{Pt}$ in the ultimately formed $\mathrm{Pt}-\mathrm{Ce}$ residue seems to be stable and with the ageing of the trap is

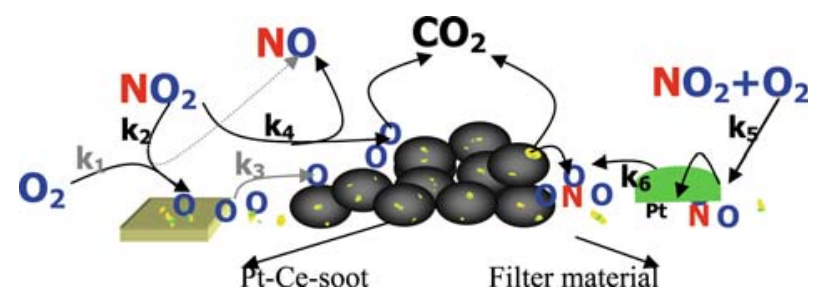

Scheme 1. Soot oxidation mechanism over $\mathrm{Pt}-\mathrm{Ce}$-soot generated from fuel-borne catalyst.

expected to improve the $\mathrm{NO}$ conversion to $\mathrm{NO}_{2}$ significantly. There is still room for improvement in the fuelborne catalyst activity, for example by decreasing the sulphur content present in the diesel fuel and, therefore, the inactive cerium-sulphate phases can be decreased and most of the ceria could be utilised for the soot oxidation through the nitrate route.

\section{Conclusions}

$\mathrm{Fe}-$, Pt-Ce- and Ce-soot are oxidised at a lower temperature with $\mathrm{O}_{2}$ compared with $\mathrm{Pt}$-soot and the opposite trend is observed with $\mathrm{NO}+\mathrm{O}_{2}$. NO is oxidised to $\mathrm{NO}_{2}$ more efficiently over the Pt-soot, whereas it is more efficiently utilised over the Ce- and $\mathrm{Pt}-\mathrm{Ce}$-soot samples. Soot oxidation under different feed gas conditions suggests that in the presence of $\mathrm{NO}_{2}+\mathrm{O}_{2}$ nitrate species are involved in the oxidation over $\mathrm{Ce}-$ and $\mathrm{Pt}-$ Ce-soot samples. Different oxidation species with decreasing order of activity which are responsible for the fuel-borne catalysts, in general, are suggested as: (1) nitrates, (2) $\mathrm{NO}_{2}$, (3) lattice oxygen, and (4) gas-phase oxygen. All the above species are involved in the oxidation of the Pt-Ce-soot which is the most easily to be oxidised soot under practical conditions.

\section{References}

[1] R.J. Farrauto and K.E. Voss, Appl. Catal. B: Environ. 10 (1996) 29.

[2] K. Kimura, T.L. Alleman, S. Chatterjee and K. Hallstrom, SAE paper 2004-01-0079 (Detroit, 2004).

[3] R. Allnsson, C. Goersmann, M. Lavenius, P. Phillips, A.J. Uusimaki and A.P. Walker, SAE paper 2004-01-0072 (Detroit 2004).

[4] T. Campenon, P. Wouters, G. Blanchard, P. Macaudiere and T. Seguelong, SAE paper 2004-01-0071 (Detroit, 2004).

[5] J.P.A. Neeft, M. Makkee and J.A. Moulijn, Chem. Eng. J. 64 (1996) 295.

[6] S.J. Jelles, R.R. Krul, M. Makkee, J.A. Moulijn, G.J.K. Acres and J.D. Peter-Hoblyn, SAE 1999-01-0113 (Detroit, 1999).

[7] S.J. Jelles, M. Makkee and J.A. Moulijn, Top. Catal. 16 (2001) 269.

[8] L. Retailleau, R. Vonarb, V. Perrichon, E. Jean and D. Bianchi, Energy Fuels 18 (2004) 872.

[9] S.J. Jelles, Ph.D. Thesis (TU Delft, The Netherlands, 1999).

[10] A. Bueno-Lopez, K. Krishna, M. Makkee and J.A. Moulijn, J. Catal. 230 (2005) 237. 